\title{
Comparison of the copper and molybdenum status of year- ling steers grazing reclaimed mined-land and native range
}

\author{
J.F. KARN AND L. HOFMANN
}

\section{Abstract}

Spoil material replaced after strip mining for lignite coal may differ from the original top soll with respect to concentrations of copper ( $\mathrm{Cu}$ ) and molybdenum (Mo), consequently levels of these elements may be affected in plants grown on this soll. The objective of the study was to compare the $\mathrm{Cu}$ and Mo status of yearling steers grazing mined-land and native range forage to determine whether mined-land grazed steers were more prone to molybdenosis and/or Cu deficiency. Vegetation samples were collected from both mined-land and native range pastures. Copper was marginal and Mo was slightly high, for beef cattle, in forage obtained from both study sites. Blood serum and liver biopsy samples were taken from yearling steers at the initiation and termination of graxing on reclaimed mined-land and native range in 1978, 1979, 1982, and 1983. For the 4 years, there was no significant difference between forage sources with respect to $\mathrm{Cu}$ and Mo levels in the liver or Mo levels in the serum. However, serum Cu was slightly $(P<$.10) lower in steers graxing on mined-land. Liver $\mathrm{Cu}$ levels were marginal in steers graxing on efther mined-land or native range. Initial liver Mo levels were slightly above normal but did not increase to levels expected if animals were consuming a diet excessively high in Mo. No symptoms of $\mathrm{Cu}$ deficiency or molybdenosis were observed during the course of the study. However, marginal serum, liver and forage $\mathrm{Cu}$ levels measured suggest that central North Dakota ranchers should be alert to the possibility of a $\mathrm{Cu}$ deficiency, whether cattle are graxing reclaimed mined-land or native range.

Key Words: strip mining, copper deffeiency, molybdenosis

Strip mining for lignite coal is an on-going activity in North Dakota and other northern Great Plains states. Following reclamation, the land, in many cases, is seeded to a perennial forage crop and used for grazing. Because spoil material with unsuitable concentrations of copper $(\mathrm{Cu})$ and molybdenum $(\mathrm{Mo})$ is within reach of the plant's roots, it has been suggested by Erdman et al., (1978) that a potential exists for molybdenosis in cattle and sheep grazing these forages. Sweet clover (Melilotus officinalis) sampled by Erdman et al. (1978) contained $>5 \mathrm{mg} / 1 \mathrm{Mo}$ at 5 of 8 mine sites sampled in the northern plains. Copper and Mo levels in individual forage species reported by Newman and Munshower (1984) were highest in forage grown on bare spoils. Molybdenum levels were higher for legumes than for grass, but no values were reported $>10$ $\mathrm{mg} / \mathrm{l}$, the level suggested by Kubota (1975) above which molybdenosis may occur. Underwood (1977) reported that connective tissue changes occurred in sheep grazing pastures containing from $5-20 \mathrm{mg} / 1 \mathrm{Mo}$, but Ward (1978) indicated the minimum toxic Mo level on fresh pasture was $20 \mathrm{mg} / \mathrm{l}$. Ward (1978) also suggested that molybdenosis may occur when the Cu:Mo ratio is less than 2:1.

Soils containing high concentrations of Mo are generally found in Nevada and California (Kubota 1975). However, metabolic problems similar to molybdenosis were reported in cattle grazing

\footnotetext{
Authors are animal scientist and research agronomist, respectively, USDA-ARS, Northern Great Plains Rexearch Laboratory, P.O. Box 459, Mandan, ND 58554.

Contribution from Northern Great Plains Research Laboratory, USDA-ARS

The authors wish to thank Mr. Terrence R. Shuler, chemist, USDA-ARS, Human Nutrition Research Center, Grand Forks, North Dakota, for his contribution to molybdenum analysis of the samples.

Manuscript accepted 21 March 1989.
}

forage grown on spoil materials containing high Mo and $\mathrm{Cu}$ levels exposed as a result of a clay mining operation in Missouri (Ebens et al. 1973). Molybdenosis also has been reported in southwest North Dakota resulting from soil contamination by a uraniferous lignite coal ashing plant (Christianson and Jacobson 1970). While forage $\mathrm{Mo}$ and $\mathrm{Cu}$ levels may be indicative of the potential for a toxicity problem, the Committee on Mineral Nutrition (1973) indicated that liver and, to a lesser extent, serum were the most appropriate materials to examine for molybdenosis or $\mathrm{Cu}$ deficiency.

Although $\mathrm{Cu}$ and $\mathrm{Mo}$ levels in forage grown on reclaimed mined-land have been reported, animal data assessing the potential for molybdenosis are lacking. Thus, the objective of this study was to measure $\mathrm{Cu}$ and Mo levels in yearling steers grazing reclaimed mined-land forage and adjacent native range to determine whether mined-land forage presented a health hazard to grazing cattle.

\section{Materials and Methods}

The study area, located near Center, North Dakota, consisted of a reclaimed strip mined-land site and adjacent native range. The mined site had been stripped for lignite coal during the late 1960 's. Pre-mining soils were classified as Cabba (loamy, mixed, calcareous, frigid, shallow Typic Ustorthents) and Sen (fine-silty, mixed Typic Haploborolls). Spoil materials were characterized physically and chemically by Bauer et al. (1976). Five years before initiation of the $\mathrm{Cu}$-Mo study, the mined area was reshaped and covered with clay loam topsoil to a thickness of $9.7 \mathrm{~cm}$. The area was seeded to a mixture of 'Lincoln' smooth bromegrass (Bromus inermis Leyss.), 'Nordan' crested wheatgrass [Agropyron desertorum (Fisch. Ex Link) Schult.], intermediate wheatgrass [Agropyron intermedium (Host) Beauv.], 'Vernal' alfalfa (Medicago sativa L.), and yellow sweetclover (Melilotus officinalis Lam.) Vegetation on the native range site was primarily blue grama (Bouleloua gracilis Lagasca ex Griffiths) and sedges (Carex spp.).

In 1978 and 1979,3 steers were assigned to graze on reclaimed mined-land and 3 on native range each year, for a total of 12 steers (3 steers/pasture for 2 years). Utilization of both pastures was approximately $80 \%$. In 1982 and 1983 a different set of pastures consisting of 4 mined-land, and 2 native range, were used to facilitate replication of pastures. Two of the mined-land pastures had previously been lightly utilized (35\%) and 2 had had a combination of moderate (47\%) and heavy (93\%) use (Hofmann and Ries 1988). These grazing treatments resulted in species and forage production carryover effects among pastures, thus, in the study reported here, light and heavy utilization mined-land pastures refers to previous grazing treatments. In 1982 and 1983, all minedland and native pastures were stocked at the same rate. Drinking water for the cattle used in the study was not available at the study site, thus it was hauled as needed from the Northern Great Plains Research Laboratory $50 \mathrm{~km}$ away.

In 1982, one steer was assigned to each of the 6 pastures for a total of 6 steers, while in 1983 two steers were assigned to each of the 6 pastures for a total of 12 steers. Steers were blood sampled and liver biopsied at initiation and termination of each grazing period: on 22 May and 8 August, 1978, 1 June and 3 August, 1979, 
Table 1. Copper and molybdenum levels averaged over sampling dates for forage grown on rechimed mined-land and native range in 1982 and 1983.

\begin{tabular}{|c|c|c|c|c|c|c|c|c|c|}
\hline \multirow[b]{2}{*}{ Year } & \multicolumn{3}{|c|}{ Copper } & \multicolumn{3}{|c|}{ Molybdenum } & \multicolumn{3}{|c|}{ Cu:Mo Ratio' } \\
\hline & Native & Mined-LU² & Mined-HU2 & Native & Mined-LU & Mined-HU & Native & Mined-LU & Mined-HU \\
\hline $\begin{array}{l}1982^{3} \\
1983\end{array}$ & $\begin{array}{l}2.8^{2} \\
3.2\end{array}$ & $\begin{array}{c}\text { ag/1 (dry basis } \\
3.0^{\circ} \\
3.2\end{array}$ & $\begin{array}{l}4.5^{b} \\
3.6\end{array}$ & $\begin{array}{r}1.3 \\
1.6\end{array}$ & $\begin{array}{c}\text { ng/l (dry basi } \\
1.2 \\
1.4\end{array}$ & $\begin{array}{c}1.4 \\
1.6\end{array}$ & $\begin{array}{l}2.8^{\star} \\
2.2\end{array}$ & $\begin{array}{l}2.6^{\circ} \\
2.7\end{array}$ & $\begin{array}{l}3.7^{b} \\
2.7\end{array}$ \\
\hline
\end{tabular}

IAll ratios show only the first value of the ratio, the second value is 1 in all cases.

2Mined-LU = mined-land previous history light utilization (35\%).

Mined-HU = mined-land previous history moderate (47\%) and heavy utilization (93\%).

3Pasture means averaged over sampling dates for an element or ratio with different letters, differ $(P<10)$ according to Student-Neweman-Keuls' Test.

24 May and 24 September, 1982, and 19 May and 3 October, 1983. No data were collected in 1980 and 1981 . Serum was separated from whole blood samples and frozen until it could be analyzed. Liver samples were kept on ice as they were collected, then rinsed with deionized water and frozen until analysis could be completed.

Forage samples were obtained in July, 1978, and June and August, 1979, by hand-clipping plants and plant parts similar to those being grazed. Random grab samples of forage were obtained from 0.9 by $3.0-\mathrm{m}$ cutter bar mower strips (1/pasture) on $15 \mathrm{June}$, 21 July, 18 August, and 4 October in 1982 and on 1 June, 2 August, and 27 September 1983. Samples were also collected from ungrazed exclosures in the pastures at the same time by the same method. Forage samples were dried at $70^{\circ} \mathrm{C}$ and ground through a 1-mm screen prior to analysis. Serum, liver, and forage samples were prepared for analysis according to procedures outlined by Fick et al. (1976). Copper was determined by atomic absorption spectrophotometry and Mo was analyzed by flameless atomic absorption spectrophotometry using a graphite furnace. Changes in serum and liver $\mathrm{Cu}$ and $\mathrm{Mo}$ levels between initial and final samples were analyzed in order to correct for differences in initial values between animals.

Animal data for 1978 and 1979 were analyzed together as a randomized complete block by analysis of variance, with pastures considered fixed and years random. Data for 1982 and 1983 and for all 4 years together were analyzed in the same manner. Utilization rates were most comparable between native range and lightly utilized mined-land pastures in 1982 and 1983; thus only data from these pastures were used when all 4 years were analyzed together. Forage data were analyzed for 1982 and 1983 separately as a randomized complete block with pastures considered fixed and sampling times considered random. Treatment means, when there were more than 2, were compared with the Student-NewmanKeul's Test. Data were considered significant at the $10 \%$ level of probability.

\section{Results and Discussion}

\section{Forage}

In July 1978, $\mathrm{Cu}$ and Mo levels in forage from grazed minedland and native range were 6.2 and $1.6 \mathrm{mg} / 1$, and 7.8 and $0.6 \mathrm{mg} / 1$, respectively. In 1979, forage $\mathrm{Cu}$ from grazed mined-land and native range was 10.0 and $10.7 \mathrm{mg} / 1$, respectively, in June and 11.4 and $2.8 \mathrm{mg} / 1$, respectively, in August. Forage Mo on mined-land was 2.7 and $3.0 \mathrm{mg} / \mathrm{l}$ in June and August 1979, respectively, but on native range it was only about $1 / 4$ as high.

Forage $\mathrm{Cu}$ and Mo levels did not vary significantly $(P>0.1)$ among sampling dates in either 1982 or 1983; thus only pasture means are presented in Table 1. However, the Cu:Mo ratios did differ significantly among all 4 sampling dates averaged over pastures (June, 3.7:1, July, 2.9:1, August, 1.4:1 and October, 4.2:1) in 1982. The Cu:Mo ratio for August was well below the 2:1 ratio suggested by Ward (1978) as a threshold was well below which $\mathrm{Cu}$ deficiencies were likely to occur. In 1982 the forage $\mathrm{Cu}$ levels and the Cu:Mo ratio (Table 1) were higher on the heavily utilized mined-land pasture than either native range or the lightly utilized mined-land pastures. Forage $\mathrm{Cu}$ and $\mathrm{Mo}$ levels averaged over sampling dates from the exclosures were 3.9 and $1.2 \mathrm{mg} / 1$ and 2.4 and $1.0 \mathrm{mg} / \mathrm{l}$, respectively, from mined-land and native range. These values were comparable to levels in grazed forage (Table 1).

In 1983 there were no significant differences in $\mathrm{Cu}$ or Mo levels or in Cu:Mo ratios among pastures (Table 1) or sampling dates (data not shown). Molybdenum levels tended to be higher and the $\mathrm{Cu}: \mathrm{Mo}$ ratios lower than in 1982. Forage $\mathrm{Cu}$ and Mo levels were only about $60 \%$ as high as levels reported by Erdman et al. (1978) for yellow sweet clover collected at a mine site near Beulah, ND. Forage $\mathrm{Cu}$ levels for 1982 and 1983 ranged from 1.6 to $6.6 \mathrm{mg} / \mathrm{l}$, with most values in the $3 \mathrm{mg} / 1$ range (Table 1). The National Research Council (1984) suggests that diet Cu levels lower than 3 to $5 \mathrm{mg} / \mathrm{l}$ may result in subnormal plasma and liver $\mathrm{Cu}$ levels.

Table 2. Copper and molybdenum levels in the serum and liver of yearling steers graxing on mined-land and mative range, average of 1978 and 1979 samples.

\begin{tabular}{|c|c|c|c|c|c|c|c|c|}
\hline \multirow[b]{2}{*}{ Pasture } & \multicolumn{4}{|c|}{ Serum } & \multicolumn{4}{|c|}{ Liver' } \\
\hline & Initial & Final & Change & $\mathbf{S E}^{2}$ & Initial & Final & Change & SE \\
\hline & \multicolumn{8}{|c|}{ Copper $(\mathrm{mg} / \mathrm{l})$} \\
\hline $\begin{array}{l}\text { Mined } \\
\text { Native range }\end{array}$ & $\begin{array}{l}0.87 \\
0.85\end{array}$ & $\begin{array}{l}0.65 \\
0.78\end{array}$ & $\begin{array}{l}-0.22 \\
-0.07\end{array}$ & $\begin{array}{l}0.02 \\
0.02\end{array}$ & 34.1 & $\begin{array}{l}24.1 \\
20.5\end{array}$ & $\begin{array}{l}-10.0 \\
-20.6^{3}\end{array}$ & $\begin{array}{l}0.3 \\
0.3\end{array}$ \\
\hline Mean & 0.86 & 0.72 & & & 37.6 & 22.3 & & \\
\hline $\begin{array}{l}\text { Mined } \\
\text { Native range }\end{array}$ & $\begin{array}{l}0.09 \\
0.08\end{array}$ & $\begin{array}{l}0.04 \\
0.01\end{array}$ & $\begin{array}{l}-0.05 \\
-0.07\end{array}$ & $\begin{array}{l}\text { Molyl } \\
0.002 \\
0.002\end{array}$ & $\begin{array}{r}(\mathrm{mg} / \mathrm{l}) \\
4.9 \\
5.1\end{array}$ & $\begin{array}{l}4.8 \\
3.9\end{array}$ & $\begin{array}{l}-0.1 \\
-1.2\end{array}$ & $\begin{array}{l}0.4 \\
0.4\end{array}$ \\
\hline Mean & 0.08 & 0.02 & & & 5.0 & 4.4 & & \\
\hline
\end{tabular}

'Levels are expressed on a dry matter basis.

${ }^{2}$ Standard error the mean $=\frac{\sqrt{\mathrm{EMS}}}{\mathrm{N}}$, where EMS $=$ error mean square used to test pastures and $\mathrm{N}=$ the number of values $/ \mathrm{mean}$.

${ }^{3}$ Means in the same column for the same element differ $(\mathcal{P}<$.10) according to Student-Newman-Keuls' Test. 
Table 3. Copper and molybdenum levela in the serum and liver of yearling steen graxing on mined-land and native range, average of 1982 and 1983 samples.

\begin{tabular}{|c|c|c|c|c|c|c|c|c|}
\hline \multirow[b]{2}{*}{ Pasture } & \multicolumn{4}{|c|}{ Serum } & \multicolumn{4}{|c|}{ Liver' } \\
\hline & Initial & Final & Change & $\mathrm{SE}^{2}$ & Initial & Final & Change & SE \\
\hline & \multicolumn{8}{|c|}{ Copper (mg/l) } \\
\hline $\begin{array}{l}\text { Mined-LU³ } \\
\text { Mined-HU³ } \\
\text { Native range }\end{array}$ & $\begin{array}{l}0.42 \\
0.52 \\
0.54\end{array}$ & $\begin{array}{l}0.30 \\
0.50 \\
0.58\end{array}$ & $\begin{array}{l}-0.12 \\
-0.02 \\
+0.04\end{array}$ & $\begin{array}{l}0.04 \\
0.04 \\
0.04\end{array}$ & $\begin{array}{l}27.0 \\
27.2 \\
29.4\end{array}$ & $\begin{array}{l}19.0 \\
16.8 \\
48.9\end{array}$ & $\begin{array}{l}-8.0 \\
-10.4 \\
+19.5\end{array}$ & $\begin{array}{l}4.6 \\
4.6 \\
4.6\end{array}$ \\
\hline Mean & 0.50 & 0.46 & & & 27.9 & 28.2 & & \\
\hline $\begin{array}{l}\text { Mined-LU } \\
\text { Mined-HU } \\
\text { Native range }\end{array}$ & $\begin{array}{l}0.03 \\
0.04 \\
0.04\end{array}$ & $\begin{array}{l}0.09 \\
0.04 \\
0.12\end{array}$ & $\begin{array}{r}+0.06 \\
0.00 \\
+0.08\end{array}$ & $\begin{array}{l}\text { Moly } \\
0.02 \\
0.02 \\
0.02\end{array}$ & $\begin{array}{r}(\mathrm{mg} / \mathrm{l}) \\
6.4 \\
5.1 \\
5.2\end{array}$ & $\begin{array}{l}6.8 \\
7.4 \\
5.7\end{array}$ & $\begin{array}{l}+0.4 \\
+2.3 \\
+0.5\end{array}$ & $\begin{array}{l}0.7 \\
0.7 \\
0.7\end{array}$ \\
\hline Mean & 0.04 & 0.08 & & & 5.6 & 6.6 & & \\
\hline
\end{tabular}

'Levels are expressed on a dry matter basis.

2Standard error the mean $=\frac{\sqrt{\text { EMg }}}{\mathrm{N}}$, where EMS = error mean square used to test pastures and $\mathrm{N}=$ the number of values $/$ mean.

${ }^{3}$ Mined-LU = mined-land previous history light utilization (35\%).

Mined-HU = mined-land previous history moderate (47\%) and heavy utilization (93\%).

\section{Animals}

Mean serum Cu levels for 1978 and 1979 were not significantly different between steers grazing on mined-land and steers grazing on native range (Table 2). Initial and final serum $\mathrm{Cu}$ levels were in the adequate range $(>0.65 \mathrm{mg} / \mathrm{l})$ according to the Committee on Mineral Nutrition (1973). Mean initial liver $\mathrm{Cu}$ levels for steers grazing on both mined-land pastures and native range were marginal ( $<50 \mathrm{mg} /$ l) Committee on Mineral Nutrition 1973). During the approximately 70-day grazing season, liver $\mathrm{Cu}$ declined for steers in both pastures, but decline was greatest $(P<10)$ for steers on native range. Final liver $\mathrm{Cu}$ levels for steers on both mined-land and native range were near the severe deficiency level $(<20 \mathrm{mg} / \mathrm{l})$ (Committee on Mineral Nutrition 1973). The average liver $\mathrm{Cu}$ level for mature cattle is $200 \mathrm{mg} / \mathrm{l}$ with a range of 23 to $409 \mathrm{mg} / \mathrm{l}$, according to Underwood (1977), with liver $\mathrm{Cu}$ ranging from 3 to 32 $\mathrm{mg} / \mathrm{l}$ with a mean of $11.5 \mathrm{mg} / \mathrm{l}$ for mature cattle that are $\mathrm{Cu}$ deficient. Tejada (1984) reported that the critical liver $\mathrm{Cu}$ level ranged between $25-75 \mathrm{mg} / \mathrm{l}$.

Serum and liver Mo in 1978 and 1979 tended to decrease during the grazing period, but there was no significant difference between steers grazing on mined-land and native range (Table 2). The critical liver Mo reported by Tejada (1984) was $4 \mathrm{mg} / \mathrm{l}$. Initial and final liver Mo levels ranged from 3.9 to $5.1 \mathrm{mg} / 1$ for steers on both pastures. Underwood (1977) stated that adult sheep and cows retained Mo concentrations to $25-30 \mathrm{mg} / \mathrm{l}$ in their livers when they were ingesting moderately large amounts of the element. These levels rapidly returned to a normal range of $2-4 \mathrm{mg} / 1$ when exces- sive levels of Mo were removed from the diet. This suggests that liver Mo for steers used in this study may have been slightly above normal, but that forage Mo was not high enough to cause a further increase in liver Mo levels.

In 1982 and 1983 (Table 3) serum $\mathrm{Cu}$ in steers did not change significantly among pastures during the approximately 124-day grazing season. Liver $\mathrm{Cu}$ also did not change significantly between steers grazing mined-land and native range, but there was a trend for liver $\mathrm{Cu}$ to increase in steers grazing native range and to decline in steers grazing on mined-land. Mean final liver $\mathrm{Cu}$ levels from steers grazing on mined-land were below the $20 \mathrm{mg} / 1$ level suggested by the Committee on Mineral Nutrition (1973) as the level below which severe deficiency and usually clinical $\mathrm{Cu}$ deficiency signs appear. In 1978 and 1979 serum and liver Mo appeared to decrease slightly during the 70-day grazing period, but in 1982 and 1983 over a 124-day grazing season, the reverse appeared to be true. However, there was no significant difference among pastures, and liver Mo levels were in the same range as in 1978 and 1979.

Combined data for the 4 years (Table 4) show a significantly greater decline in serum $\mathrm{Cu}$ in steers grazing on the mined-land than in steers grazing on native range. Mean liver $\mathrm{Cu}$ over the 4 years tended to decline more for steers on mined-land during the grazing period, but results were not significant. In 1978 and 1979 the decline in liver $\mathrm{Cu}$ was greatest for steers on native range, while in 1982 and 1983 liver $\mathrm{Cu}$ appeared to increase in steers grazing on native range and decrease in steers grazing the mined-land pastures. Liver $\mathrm{Cu}$ was quite variable in our study: levels for individual

Tahle 4. Summary of copper and molybdenum levels in the serum and liver of yearling steers grazing on mined-land and native range, average of 1978 , 1979,1982 , and 1983 samples.

\begin{tabular}{|c|c|c|c|c|c|c|c|c|}
\hline \multirow[b]{2}{*}{ Pasture } & \multicolumn{4}{|c|}{ Serum } & \multicolumn{4}{|c|}{ Liver $^{1}$} \\
\hline & Initial & Final & Change & $\mathrm{SE}^{2}$ & Initial & Final & Change & SE \\
\hline $\begin{array}{l}\text { Mined } \\
\text { Native range }\end{array}$ & $\begin{array}{l}0.64 \\
0.70\end{array}$ & $\begin{array}{l}0.48 \\
0.68\end{array}$ & $\begin{array}{l}-0.16 \\
-0.02^{3}\end{array}$ & $\begin{array}{r}C c \\
0.02 \\
0.02\end{array}$ & $\begin{array}{l}g / 1) \\
30.6 \\
35.3\end{array}$ & $\begin{array}{l}21.6 \\
34.7\end{array}$ & $\begin{array}{l}-9.0 \\
-0.6\end{array}$ & $\begin{array}{l}4.6 \\
4.6\end{array}$ \\
\hline Mean & 0.67 & 0.58 & & & 32.9 & 28.1 & & \\
\hline $\begin{array}{l}\text { Mined } \\
\text { Native range }\end{array}$ & $\begin{array}{l}0.06 \\
0.06\end{array}$ & $\begin{array}{l}0.06 \\
0.07\end{array}$ & $\begin{array}{r}0.00 \\
+0.01\end{array}$ & $\begin{array}{l}\text { Moly } \\
0.01 \\
0.01\end{array}$ & $\begin{array}{c}(\mathrm{mg} / \mathrm{l}) \\
5.7 \\
5.2\end{array}$ & $\begin{array}{l}5.8 \\
4.8\end{array}$ & $\begin{array}{l}+0.1 \\
-0.4\end{array}$ & $\begin{array}{l}0.4 \\
0.4\end{array}$ \\
\hline Mean & 0.06 & 0.06 & & & 5.4 & 5.3 & & \\
\hline
\end{tabular}

${ }^{1}$ Levels are expressed on a dry matter basis.

${ }^{2}$ Standard error the mean $=\frac{\sqrt{\mathrm{BM}}}{\mathrm{N}}$, where EMS $=$ error mean square used to test pastures and $\mathrm{N}=$ the number of values $/$ mean.

${ }^{3}$ Means in the same column for the same element differ $(P<.10)$ according to Student-Newman-Keuls' Test. 
animals ranged from 17 to 73 and from 8 to $82 \mathrm{mg} / \mathrm{l}$ at the initial sampling times in 1978 and 1979 and 1982 and 1983 , respectively. Termination values were only slightly less variable. The range in liver $\mathrm{Cu}$ was greater than had been anticipated and no doubt contributed to the variability of the results. However, the values were all on the lower end of the concentration scale reported for normal liver $\mathrm{Cu}$ and the range in values reported in the literature suggest that these results may not be unusual. Mean initial and final liver $\mathrm{Cu}$ values for the 4 years were in the area considered marginal ( $<50 \mathrm{mg} / \mathrm{l})$ by the Committee on Mineral Nutrition (1973), regardless of the pasture grazed.

Data suggest that yearling steers in this study had liver $\mathrm{Cu}$ and Mo levels that, according to literature, were in the marginal range with respect to prevention of $\mathrm{Cu}$ deficiency. However, the change in serum or liver Cu or Mo levels during the grazing periods used in the study were not consistent among years, even though forage on both mined-land and native range was marginally low in $\mathrm{Cu}$ and marginally high in Mo for beef cattle. The relatively constant liver Mo levels, however, suggest that dietary Mo levels on either minedland or native range were not excessive.

High concentrations of dietary sulfur (S) may enhance the adverse affect of Mo on Cu availability (Smart et al. 1981). Langlands et al. (1981) indicated that with sheep, when Mo concentrations exceeded $10 \mathrm{mg} / \mathrm{l}, \mathrm{S}$ had a greater adverse affect on the availability of $\mathrm{Cu}$ than when Mo concentrations were less than 5 $\mathrm{mg} / \mathrm{l}$. In the study reported here forage Mo concentrations were generally in the $1-3 \mathrm{mg} / \mathrm{l}$ range; thus it is unlikely that $S$ played any significant role in $\mathrm{Cu}$ availability.

No animals used in this study showed any symptoms of $\mathbf{C u}$ deficiency, molybdenosis or impaired performance, and the rancher whose land was used for the study had never observed $\mathrm{Cu}$ deficiency symptoms in his animals. However, $\mathrm{Cu}$ deficiencies have been documented with cattle grazing native range in North Dakota and the marginal nature of $\mathrm{Cu}$ levels in forage and animal tissues reported in this study suggest that ranchers in central North Dakota should be alert to the possibility of a $\mathrm{Cu}$ deficiency, whether their cattle are grazing on native range or on reclaimed mined-land.

\section{Literature Cited}

Bauer, A., G.W. Gee, and J.E. Glley. 1976. Physical, chemical and biological aspects of reclamation of strip-mined lands in western North Dakota. Old West Regional Commission Grant No. 10470016 (Contract No. NDSPG-NDAES-0001). North Dakota State Planning Division. Bismarck.

Chritianson, G.A., and G.A. Jacobeon. 1970. Report on molybdenosis in farm animals and its relationship to a uraniferous lignite ashing plant. North Dakota State Department of Health and Engineering Service, Bismarck.

Committee on Mineral Nutrition, The Hague. 1973. Tracing and treating mineral disorders in dairy cattle. Center for Agricultural Publishing and Documentation, Wageningen, The Netherlands.

Ebens, R.J., J.A. Erdman, G.L. Feder, A.A. Care, and L.A. Selby 1973. Geochemical anomalies of a claypit area, Callaway County, Missouri and related metabolic imbalance in beef cattle. Geol. Survey Prof. Paper 807.

Erdman, J.A., R.J. Ebem, and A.A. Case. 1978. Molybdenosis: A potential problem in ruminants grazing on coal mine spoils. J. Range Manage. 31:34-36.

Fick, K.R., S.M. Miller, J.D. Funk, L.R. MeDowell, and R.H. Houser. 1976. Methods of mineral analysis for plant and animal tissues. Department of Animal Science, Univ. Florida, Gainesville.

Hofmann, L., and R.E. Ries. 1988. Vegetation and animal production for reclaimed mined land pastures. Agron. J. 80:40-44.

Kubota, J. 1975. Areas of molybdenum toxicity to grazing animals in the western states. J. Range Manage. 28:252-256.

Langlands, J.P., J.E. Bowles, G.E. Donald, A.J. Smith, and D.R. Paull. 1981. Copper status of sheep grazing pastures fertilized with sulfur and molybdenum. Aust. J. Agr. Res. 32:479-486.

National Research Couneil. 1984. Nutrient requirements of domestic animals. Nutrient requirements of beef cattle. 6th Ed. Nat. Acad. Sci. Washington, DC.

Neuman, D.R., and F.F. Munshower. 1984. Copper and molybdenum uptake by forages crown on coal mine spoils. J. Range Manage. 37:517-520.

Smart, M.E., J. Gudmuadson, and D.A. Chriatensen. 1981. Trace mineral deficiencies in cattle: A review. Can. Vet. J. 22:372-376.

Tejads, R. 1984. Evaluation of the mineral status of cattle in specific regions in Guatemala. Ph.D. Diss., Center for Tropical Agr. Internat. Prog., Inst. of Food and Agr. Sci. Univ. Florida, Gainesville.

Underwood, E.J. 1977. Trace elements in human and animal nutrition, 4th Ed. Academic Press, New York, San Francisco, London, a subsidiary of Harcourt Brace Jovanovich, Pub.

Ward, G.M. 1978. Molybdenum toxicity and hypocuprosis in ruminants: A review. J. Anim. Sci. 46:1078-1085. 